\title{
The Joy of the Easter Egg and the Pain of Numb Hands: The Augmentation and Limitation of Reality Through Video Games
}

\author{
Enrique Uribe-Jongbloed ${ }^{1}$ \\ Tobias M. Scholz $z^{2}$ \\ Hernán David Espinosa-Medina ${ }^{3}$
}

Recibido: 2015-02-17

Enviado a pares: $2015-02-24$
Aprobado por pares: 2015-03-21

Aceptado: 2015-04-06

DOI: 10.5294/pacla.2015.18.4.9

Para citar este artículo / To reference this article / Para citar este artigo

Uribe-Jongbloed, E., Scholz, TM. \& Espinosa-Medina, H.D. (Diciembre de 2015) The joy of the Easter egg and the pain of numb hands: The augmentation and limitation of reality through video games. Palabra Clave, 18(4), 1167-1195. DOI: 10.5294/pacla.2015.18.4.9

\section{Abstract}

Becoming immersed in a world where our perception of reality is highly mediated allows for the creation of an audiovisual lexicon that expands over many platforms and times. In this context we might observe the case of video games which, as a medium, does not limit themselves to the creation of puzzles to be solved, to pretend participation in the Rock and Roll world, or lead us to unexpected damages to our "flesh". Games allow us different levels of enjoyment and also lead us to discover the physical limits of our bodies within the expansion of our senses. Furthermore, hidden in many of these games we discover many hints, influences, remnants, appropriations and quotes, expanding the web of signs and significations far beyond the limits of the games themselves. However, the extent and consequences of video games as entertainment and communicational devices surpasses 
their potential for representation and signification, and even impact aspects of our lives such as our physiognomy and psychology-we experience carpal tunnel syndrome, addiction and withdrawal symptoms, and we delve in debates that isolate us or make us only socially able within the confines of virtual worlds. All in all, video games have become part and parcel of our existence, extensions of our perspectives of the world that surround us. Games shape our rational cognition, they build upon our new relational memories, but they also show the limitations of our physical rootedness. This article hopes to elicit an exploration into the reality of the media and mediatized reality of our physical limitations.

\section{Keywords}

Video games; ludology; narratology; media ecology; reality construction (Source: Unesco Thesaurus). 


\section{La alegría de los huevos de Pascua y el dolor de las manos entumecidas: el aumento y la limitación de la realidad a través de los videojuegos}

\section{Resumen}

Sumergirse en un mundo en el que nuestra percepción de la realidad está muy mediatizada permite la creación de un léxico audiovisual que se expande sobre muchas plataformas y tiempos. En este contexto, podemos observar el caso de los videojuegos que, como un medio, no se limitan a la creación de rompecabezas para resolver, de fingir participación en el mundo del Rock \& Roll, o nos llevan a daños inesperados a nuestra "carne". Los videojuegos nos permiten diferentes niveles de placer y también nos llevan a descubrir los límites físicos de nuestro cuerpo dentro de la expansión de nuestros sentidos. Además, ocultos en muchos de estos juegos descubrimos consejos, influencias, restos, asignaciones y cotizaciones, la ampliación de la red de signos y significados más allá de los límites de los propios juegos. Sin embargo, el alcance y las consecuencias de los videojuegos como entretenimiento y dispositivos comunicacionales superan sus posibilidades de representación y significación, e incluso afectan aspectos de nuestra vida como nuestra fisonomía y la psicología que experimentamos: síndrome del túnel, de adicción y síndrome de abstinencia del carpo, y ahondan en los debates que nos aíslan o nos hacen solo socialmente capaces dentro de los confines de los mundos virtuales. En este artículo se espera obtener una exploración de la realidad de los medios de comunicación y la realidad mediatizada de nuestras limitaciones físicas.

\section{Palabras clave}

Videojuegos; ludología; narratología; ecología de los medios; realidad de la construcción (Fuente: Tesauro de la Unesco). 


\section{A alegria dos Easter eggs e a dor das mãos amortecidas: 0 aumento e a limitação da realidade por meio dos videogames}

\section{Resumo}

Mergulhar num mundo no qual nossa percepção da realidade está muito midiatizada permite a criação de um léxico audiovisual que se expande sobre muitas plataformas e tempos. Nesse contexto, podemos observar o caso dos videogames que, como um meio, não se limitam à criação de quebra-cabeças para resolver, de fingir participação no mundo do rock'n'roll, ou nos levam a danos inesperados à nossa "carne". Os videogames nos permitem diferentes níveis de prazer e também nos levam a descobrir os limites físicos do nosso corpo dentro da expansão dos nossos sentidos. Além disso, oculto em muitos desses jogos, descobrimos muitas dicas, influências, fragmentos, apropriações e citações, a ampliação da rede de signos e significados que vai mais além dos limites dos próprios jogos. Contudo, o alcance e as consequências dos videogames como entretenimento e dispositivos comunicacionais ultrapassam suas possibilidades de representação e significação, e inclusive afetam aspectos da nossa vida como nossa fisionomia e psicologia - experimentamos síndrome do túnel do carpo, de vício e de abstinência-, e aprofundam nos debates que nos isolam ou nos fazem só socialmente capazes dentro dos mundos virtuais. Neste artigo, espera-se obter uma exploração da realidade dos meios de comunicação e da realidade midiatizada das nossas limitações físicas.

\section{Palavras-chave}

Videogames, ludologia, narratologia, ecologia das mídias, construção da realidade (Fonte: Tesauro da Unesco). 


\section{Video games as environment}

Video games are not bound to the television set, $\mathrm{PC}$, console or mobile in the same way that film, television or video were limited by their distribution technology. In fact, since they mix platforms (console, PC, tablet, stand-alone devices), styles, visual cues and interactions to such degree, they become much more interesting media than those before them. Video games are more than mere tools; users are able to interact with them unlike with any previous medium. It is difficult to describe them in the singular, as video game, in the same way that we do with radio, television or film (Aarseth, 1997, Chapter 1). We refer to them as video games, computer games, interactive games, and digital games. Here we use only the former to refer to all of those different types of games mediated by electronic technology. It would seem unnecessary to describe video games any further, as other media counterparts they are as much part of our reality nowadays as is the written word, the TV set and the automobile. Video games have been with us long enough that there is no ignoring them. They have blended into any part oflife and have become a natural part of society (Williams, Yee \& Caplan, 2008).

Which is why it makes sense to address video games from the perspective environments, as presented by Marshall McLuhan (1967) and further clarified by Scolari (2012). Video games take many elements from the previous media they use as inspiration or reference, and from those technological gadgets, including television sets, computers, mobile phones and, even, the written text, which previous media have used as systems, codes or platforms. Yet video games offer opportunities beyond the options previously presented by these media: the chance to interact, albeit in very different ways, from simple choice taking and physical exertion of actions to complex world-constructions. Although video games have their roots in previous media, video games create a complete new and novel environment.

This complexity makes video games difficult to classify as a medium (Wolf, 2001), yet it still seems to be the best way to address them. However, it does not stop there. Video games have not only drawn elements from previous media, integrated and emulated them, they have also generated 
interest of their own, becoming cultural products in their own right, merging with many of our aspects of everyday activity, to the point that they may be as present as their older media family members. The digital divide might not even be enough to prevent video games from reaching the cultural milieu of people all over the world, becoming part of clothing, toys, visual and musical art that may transcend the original medium. Video games are influencing previous media, which can be seen in movies, books and, recently, in the speech assistant Cortana, developed by Microsoft, which is named after an AI (Artificial Intelligence) from the video game Halo (2001). Furthermore, they are constructed within a set of intertextual relations, of which video games are but an inextricable part.

One reason for such attraction is rooted in the playfulness of video games. As Huizinga (1949) stated in the concept of homo ludens, all humans are always at play. Video games, therefore, are triggering those aspects of playfulness which spark interest for human beings. Particularly since "play is a voluntary activity, it is superfluous, it is never a task, it is distinct from 'ordinary' life, begins and then at a certain moment it is 'over'” (Huizinga, 1949, p. 7-9). Bateman (2014) makes a case at understanding video games as a form of aesthetic pleasure deriving from the uncertainty implicit in games, because

\begin{abstract}
All play is necessarily uncertain-although of course many things are uncertain that we would not consider play, let alone a game. Nonetheless, making uncertainty the frontier of all implicit game aesthetics is the only way of ensuring that all possible definitions of game will be contained within the superset of aesthetic values for play. (p. 407)
\end{abstract}

Their draw and attractiveness have made them prey of the usual debates about media effects, and current scholarship includes a great deal of articles addressing the relationship between video games and violence (see, for instance, ESA, 2014; Ferguson, 2015), in a way that is reminiscent of historical studies done for almost all previous media output. Yet, there are other spaces beyond communication and cultural studies where video games also find a niche: for instance medical studies and administration studies (Light, 2008). In medical studies, video games are linked with diminished or augmented specific bodily functions due to therapeutic or 
problematic hardware use, excessive exposure to specific types of visual or acoustic stimuli or the possibilities for rehabilitation in physiotherapy or psychotherapy (Aguilera, 2014). They also include the new tendency for video games that help stay in shape and the symbolic idea of a healthy life. In administration studies, video games present new spaces for the development of individual and collective goals, multi-player games may foster leadership skills, and gamification has become a buzz word for companies as a must-do development for their business.

The following pages hope to present a series of aspects to look at the media ecology of video games, to situate them as a topic of studies that overcomes narrow perspectives focused on effects, narrative construction, representation and interactive possibilities, and position them within a more nuanced set of interrelations that provide a larger space for analysis.

\section{How to study video games}

There are two main schools for the study of video games that tend to be presented in contrast to one another: ludology and narratology (Apperley, 2006; Atkins, 2006; Chen, 2013; Frasca, 2003; Ulas, 2014). Anderson (2013) takes part in the discussion and tries to come to a compromise of sorts. He asserts that

there resides an anxiety about how video games should be studied. Specifically, I suggest that scholars are still engaged in a struggle between ludology, or what makes video games different than other media, and narratology, or the study of video games as a narrative form not unlike film, novels, and other art. Simply put, ludology would frame games as so unique that they cannot be discussed without attempting to define their nature, while narratology takes video games' nature as granted and investigates them as any other media. The ludic anxiety about video games has shifted slightly but still remains in much contemporary scholarship regarding games' rhetoric. (p. 291)

And then he moves on to propose a way out, studying video games within the larger framework of communication studies, stating that "communicative scholarship seeks to illuminate questions relating to various 
fields, including philosophy, cultural studies, communication, etc., by using video games as sites of research" (p. 300).

This does in no way undermine studies which concern themselves with the nature of play, as the ludology strand privileges, nor those that concentrate on the narrative storylines present in most video games, including only metaphorical elements, but shows that there are other ways to take video games as a larger space of study, an environment in the sense originally presented by Marshall McLuhan (1967) and further elaborated by Eric McLuhan (2008) and Scolari (2012). McLuhan's "claim that new media has deep consequences in structuring subjectivity not just at the level of cultural content but of perceptual process" (Kline, Dyer-Witheford, \& De Peuter, 2003, p. 35), implies looking as games based on two claims, "the first is that game forms are tied to the culture in which they exist, and thus reveal its nature; the second is that games release tension" (EgenfeldtNielsen, Smith, \& Tosca, 2008, p. 28). Games tell us about how we define who we are, as a culture, and they serve to release some particular emotions, be those cathartic or interest-based - as is the case of simulations. In fact, they may even help children elaborate their imagination (Bertolini \& Nissim, 2002), and serve to equip players with a variety of useful skills and abilities (Bourgonjon, Wever, Soetaert, \& Valcke, 2015). Video games are a medium that opens up a large amount of possibilities of exploration.

Thinking about them as an environment, rather than looking into specific cases and looking at them as texts, helps us comprehend what is meant by the famous quote 'the medium is the message.' Marshall McLuhan (1996b) himself asserted that:

By stressing that the medium is the message rather than the content, I'm not suggesting that content plays no role-merely that it plays a distinctly subordinate role... By placing all the stress on content and practically none on the medium, we lose all chance of perceiving and influencing the impact of new technologies on man, and thus we are always dumfounded by —and unprepared for-the revolutionary environmental transformations induced by new media.(pp. 236-237) 
The question here is one of focus. When we concentrate on a message of a given medium, we might discover many things about that specific message, about its form and even about possible intentions of the author. However, we would know very little about the real 'message' delivered, because we ignore how much the medium defines the production systems, distribution processes, artist participations, the intertextual nature of the text, the extension of the medium in the population, and many other factors that seem to render the internal significance of the text as secondary to the value of the medium where it is inscribed. Similarly, Roncallo Dow (2011) defines the environment as a communicative framework that constitutes the world, described as

no other than the endless array of relational links that, through language, we incorporate every day and that keeps us in synchrony with others, those with whom we are immerse in language games. ${ }^{4}$ (p. 53)

Furthermore, he complements that definition by adding that

What the idea of a McLuhanian cosmology truly encompasses is the need to think about the complexity of the technical system in the era of telecommunications and how is a whole array of changes deployed, stemming from the intersystemic linkages within, which affect, precisely, the way in which the subjects understand the world and relate to their surroundings. ${ }^{5}$ (Roncallo-Dow, 2011, p. 90)

Thus,

Media function as environments, ecologies, and systems. Content is what happens within the system, and it may or may not affect the system. Technological innovation is a change that occurs to the system itself, and its impact will be profound and far-reaching. And from a systems perspective, we can understand that media do not cause certain effects in a linear manner, but rather, particular forms of communication, consciousness, and culture emerge out of particular media ecologies. (Strate, 2008, p. 135)

\footnotetext{
Own translation, emphasis on the original text.

Own translation, emphasis on the original text.
} 
What these various observations highlight is that conceiving the media as an environment is looking beyond the particularity of specific messages conveyed through them. It leads us to pay particular attention at how video games, as multiple media, shape our perception of the world as an "extension of our senses" (M. McLuhan, 1996a).

There are many aspects through which video games, as a whole, have changed the way we feel about the world that surrounds us, shaping our own version of reality. Here we explore some of them, with the aim of showing how much they have shaped our own consciousness.

\section{Happiness}

In her book Reality is Broken, McGonigal (2011) presents a radical argument about what video games may teach us about happiness in the daily life. She explores the ways in which they reinforce what can be defined as happiness, how millions of people are using them as tools for supplying these positive emotions in today's world, and how, in contrast, real life seems to behave in a manner that in many cases contradicts the positive elements of gaming. Her study points to real trends in terms of people's behavior towards games, in terms of dedication to playing and how we come to view reality and in particular instances as work and study. This reflection is hardly new and historically has been tested and studied in many forms and applied to business management, advertising and other fields with success (Light, 2008).

In basic terms McGonigal (2011) points out four ways in which games bolster happiness. First, "games challenge us with voluntary obstacles and help us put our personal strengths to better use" (p.22). This counter-intuitive idea, that by introducing unnecessary obstacles to increase the challenge of a task can effectively transform the task into something more interesting than it actually is, has to do with the natural process of learning and the way in which the brain has evolved to reward pattern seeking (Koster, 2014). Through the creation of a challenging situation that is voluntarily undertaken and that has clear and reachable goals,

We are intensely engaged, and this puts us in precisely the right frame of mind and physical condition to generate all kinds of positive 
emotions and experiences. All of the neurological and physiological systems that underlie happiness-our attention systems, our reward center, our motivation systems, our emotion and memory centersare fully activated by gameplay. (McGonigal, 2011, p. 28)

An interesting issue arises when games are compared to other forms of entertainment and shows actual psychological consequences that further supports the trends mentioned earlier, for example, in terms of Experience Sampling Methodology

researchers believe that when we consciously seek out relaxing fun, we're usually trying to reverse these negative feelings. When we seek out passive entertainment and low-engagement activities, we're using them as a counterbalance to how stimulated and overwhelmed we feel.

But by trying to have easy fun, we actually often wind up moving ourselves too far in the opposite direction. We go from stress and anxiety straight to boredom and depression. We'd be much better off avoiding easy fun and seeking out hard fun, or hard work that we enjoy, instead. (McGonigal, 2011, p. 32)

This emotional surplus amplified by a good feedback system is the second element that bolsters happiness, taking people to a state of intense focus called Flow. This state has positive and negative effects. On one hand it may generate an emotional burn down and addiction, in many cases, which may lead to a condition known as gamer's regret. On the other hand, psychologists have found tendencies towards an expansion of the self, augmented enjoyment of an experience, enhanced emotional resilience and better disposition towards task undertaking (Csikszentmihalyi, 1991, pp. 43-70). These negative and positive effects become meanings in themselves, generating diverse attitudes towards gaming even from people that do not see themselves as gamers (Martin, 2011).

These first two forms of happiness bolsters a point in many ways to how some game designers approach their deigns, hoping to capitalize on the fact that games as systems have clear, reachable, objectives with feedback systems and a strong sense of agency, either to enhance real experiences (Thiagarajan, 2015), or simply to profit from them. In this sense, the 
ludologic approach to games and their construction, especially in terms of mechanics has much to offer.

\section{Sociability}

The third happiness bolster element in games is their potential to help encourage and strengthen the development of social relations. From the ludology standpoint, games have the innate capability, through their mechanics, of helping us establish relationships by lowering social tension and friction through the sharing of goals and resources (Schell, 2015, Chapters 23-24). Moreover, positive emotions can even be argued to have evolved for the purpose of encouraging human cooperation (McGonigal, 2008, p. 8). So trough positive emotions games can actually propel participation and social engagement.

However, this socializing effect can actually be intensified if other elements closer to those analyzed and proposed in a narratology perspective are taken into account. World-building as a way of narrative exploration fits very well with the exploration experienced by gamers in many ways (Jenkins, 2004; Wolf, 2006). This playful exploration of narrative environments can actually evolve into complete cultural constructions and communities that grow and develop over time with an intense sense of belonging (Pearce, 2007).

This narratology approach actually opens the door to the last happiness booster: being part of something bigger than ourselves, of something epic (McGonigal, 2011, p. 96).

\section{Meaning Construction}

Through narrative construction we actually grant meaning to our actions and to the world around us. Similarly, stories can help us contextualize and give meaning to a goal that we consider is only achievable through the cooperative effort of hundreds, thousands or even millions of people; an overwhelming sense overtakes us and compels us to action, a sense of awe (McGonigal, 2011, p. 99). This sense of awe, as defined by McGonigal, compels people 
to participate and join in a productive effort; not by producing any value, in many cases, but by bestowing meaning.

This narrative component can be seen as a new form of mythological construction. In an age where the speed of information and the proliferation of sources of content may prove to be obstacles to mythological construction, video games force people to engage content in a more intense way, exploring the complexities of issues and being directed to make decisions and assume consequences (Rushkoff, 2011). As Rushkoff (2013, p. 95) would put it, "instead of inserting messages into games the way an author might insert a message into a book, games try to communicate through experience".

Video games are also laden with information drawn from many other previous and co-existent media forms which expand their conceptual lexicon. A video game can be understood through intertextual relationships whether as characteristics of the texts themselves, as franchise extensions of previously successful products (Brookey \& Booth, 2006), or by the appearance of Easter Eggs - joyful parodic allusions that make different texts come together into a web of relationships, increasing the pleasure derived from discovering this relationship, providing amusement, challenges and identification for the initiated (Ott \& Walter, 2000; Weinel, Griffiths, \& Cunningham, 2014) - as is the case of the series Kingdom Rush (2011). Intertextuality in video games can also address the myriad of resources available to payers as they navigate through their gaming worlds in the form of discussion forums, video walk-throughs and similar parallel texts (Schrader, Lawless, \& Mccreery, 2009). These interconnected texts provide evidence of a densely constructed social meaning, because "technologies ... create environments that affect the people who use them" (Scolari, 2012, p. 207).

Yet these meanings are not unbiased or untainted by ideology; as a myth they favor certain positions while rejecting others. Video games can be seen as a means of persuasion or, as Bogost (2007) would put it, "Procedural Rhetoric". This connects with a Barthesian construction of the myth and with the McLuhanian description of the medium (Roncallo-Dow \& UribeJongbloed, 2013). This ideological spin of video games addresses why their study necessarily takes us to assess their moral implications in our culture. 


\title{
Morality
}

There are several examples that evidence how media can be a mirror of society, such as the increase in apocalyptic and superhero movies in the wake of 9/11 (Spigel, 2004) and the proliferation of zombie narratives as a sign of cultural anxiety (Dendle, 2007). Those films are loaded with ethical positivism showing how society will prevail. Let's look at the example of the famous presidential speech on Independence Day (Emmerich, 1996):

We will not go quietly into the night! We will not vanish without a fight! We're going to live on! We're going to survive! (1:48:00)

The director externally induces such moral choices and, although they have a strong emotional impact on the viewer, they have no further impact on them. That is quite the contrary to video games, where the player is the actor, making those choices as the game progresses (Granic et al., 2014). In these cases, the player has to choose his/her path of morality, because

\begin{abstract}
unlike television, film and news media, which construct a passive experience of legal themes, video games create an active experience, going beyond mere observance and making the player participate in the construction of narratives and in-game decision-making. Where themes of justice are concerned, it is the individual player that becomes the arbiter of justice, often tasked with making decisions that allow society or individual characters to achieve retribution. (Newbery-Jones, 2015, p. 79)
\end{abstract}

Research states that players are highly entangled with non-player game characters (Weaver, \& Lewis, 2012). Decisions concerning their well-being are difficult for players and lead to moral and ethical dilemmas that players try to solve constructively (Schulzke, 2010). Players face difficult questions, like using an atom bomb in Fallout 3 (2008), allowing or restricting international border crossing in Papers, please (2013) or harvesting the little sisters in Bioshock (2007), to mention a few. Other games, such as the renowned MMORPG World of Warcraft (2004), include internal social dynamics which generate moral debates within the game play, in the form of in-game guild discussions, or off-game forum debates, prompting them to be used as a tool for moral education (Khoo, 2012). If players were as keen to be violent as 
some journalists and researchers are trying to portray them to be, why are there players trying to achieve a no-kill walkthrough via Metal Gear Solid 3 (2004) - a tactical shooter game? Furthermore, in Mass Effect (2007), where decisions by players influence the moral development of their characters and Paragons represent the good guys and Renegades the bad guys, two thirds of all players chose the Paragon path and a staggering 92\% managed to cure a genophage within the game (Totilo, 2013). They put to test and provide a more nuanced description of the challenges of moral decision. As an illustrative example, "Papers, Please (2013) demands its players to contemplate the consequences of the seemingly arbitrary geopolitical borders that maintain boundaries of inclusion and exclusion making it a useful pedagogical tool for exploring these issues" (Lellock, 2015, p. 121).

In general, video games tend to be designed to achieve some form of victory or success against an 'enemy' or opponent. Players take on the role of a hero that has to decide how such victory will be reached. Thus, they have to deal with their decisions, honing their moral sensitivity. For instan$c e$, a recent study discovered that bad behavior is increasing moral sensitivity due to the reflection on players' guilt (Grizzard et al., 2014). If film and television brought the empathy of literature closer by letting images of the suffering of others seem closer to home, video games have enabled the decision-making process of those inflicting the damage become part of the interactive experience.

\section{Changeability}

Not only morality is an important aspect that is sharpened through video games, but also the notion that everything is changeable and everything is transformable. It can be presented on a spectrum between linearity and non-linearity. Games that follow one story arc, driven by the developers instead of the players, and have similarities resemblance to the auteur theory (Scholz, 2013), are often quite linear and the players can see the possible ends of the game and the limits of their reality within it. Contrary to that linearity are sandbox games (Duncan, 2011) and open-world games (Medler, 2011), where the player can do whatever he/she wants. However, those worlds are also limited, although not in the narrow sense that linear games 
are. Players can follow the rules or live on the edge (Scholz, 2010). Any player knows that there are limits and there is freedom within games. Similar to the real world there is space to explore as well as to exploit (March, 1991). But video games give players the space to play with the changeability of such worlds and, through play, influence the world and its reality. There are several examples that state the influence of players on virtual worlds (see, for instance, Roncallo-Dow et al., 2012).

Such knowledge is beneficial concerning the perception of reality. There are aspects in the real world that can be changed and there are aspects that are fixed. Knowing those barriers and efficiently discovering those barriers help players to navigate better in the real world.

\section{Adaptability}

But if players can change worlds, the developers of those worlds can change them as well. Patches, bug fixes, expansions or new versions are popular ways of changing video games. Such changes can transform existing worlds fundamentally. Players are forced to adapt to this new environment and have to change their behavior or train new talents. The game World of Warcraft (2004) is a striking example. Due to its long history of over ten years, WoW has transformed in many ways. Especially in the case of the playable characters, such changes were and still are tremendous. Players can choose a certain class (e.g. Mage or Warrior) and with every patch those classes are "modernized" or "fixed". Such changes could include a complete overhaul of a class and players that stick with that class, have to learn and train a new play-style.

Such talent of training new skills quickly is an asset that helps in the modern volatile world.

\section{Capability}

Although video games are just for fun and for play, they are a highly effective training system (Gee, 2005).The most obvious aspect is the improvement of hand-eye coordination. Even doctors play video games to improve this capability, which leads to better performance in surgery (Rosser et al., 
2007). Furthermore information can be spread through games; so-called serious games are designed to transport certain information in playful way. Academic subjects, such as history, have been considered as likely to benefit from this gamification process, because

the inherently game-like qualities of historical research, the popularity of history-based video games, the use of games as pedagogical tools, and the movement by game studies to analyze history games point to the possibilities of developing a scholarly game. (Spring, 2014, p. 218)

Another aspect is competition in a friendly matter or puzzle-solving and logical thinking. In addition digitalization literacy is highly trained. Working in decentralized, international and virtual teams is the norm in multiplayer games. Coordinating team play with a diverse set of players for a short period is something natural for players. Especially cooperation and leadership are skills that improve within video games. Leading a guild of 25 players that are different in age, nationality and gender, is difficult. There are many guilds that are successful in their certain range. Also players know that they have to trust their partners and know that they cannot work alone to achieve their goals. The most important skill is being decisive. Players have to decide in milliseconds and live with those decisions.

All those capabilities that players learn are important and relevant for any job in the modern working world. Players are good team players, can be decisive and are truly digital inhabitants.

\section{Tenacity}

It sounds weird that players in the field of competitive gaming (or eSports) train, for ten hours a day, one and only one game, every day for a week. It also seems odd that 25 players try to master a fight against a dragon and, despite failing over 100 times, still nurse a desire to win.

They will devote hours upon hours to mastering it, endlessly fascinated by the intricacies of the system, its characters, its weapons, its properties. Figuring out strategies and tactics become core play activities. (Taylor, 2012, p. 89) 
This devotion leads to a staggering amount of 3 billion hours a week playing video games (McGonigal, 2011). Players are motivated to master the game and will do anything to reach this goal. Such behavior could be seen as something negative or even an addiction. However, video games provide them with a sense of mastery. Maybe, as McGonigal points out, reality is broken and video games are more capable of triggering that sense of mastery. This observation is nothing new and the complete concept of gamification is developed on the premise that video games are doing something right in the case of motivation. Players are not easily motivated but they know that tenacity leads to a certain goal. This goal is, contrary to most jobs, precisely defined. Furthermore, players see their progress and are motivated to invest time and energy. This tenacity is often linked to the concept of playbour (Kücklich, 2005). Failure is part of the game (Juul, 2013) and will be susceptible for trial and error (Scholz, 2010), therefore, players have a higher degree of "entrepreneurial drive" (Armstrong, \& Hird, 2009).

\section{Endurance}

Video games also help us stay in physical and cognitive shape. Video games that demand physical activity can be traced almost to their origin in arcade halls (Bogost, 2007, p. 294). Active video games -AVGs- are not a recent phenomenon, but the studies of their impact upon health have only begun recently (Peng, Crouse, \& Lin, 2013). The famous arcade hit Dance Dance Revolution (1998) has shown to be helpful as therapy for Huntington's disease (Kloos, Fritz, Kostyk, Young \& Kegelmeyer, 2013), and other types of AVGs known as exergames have been proven to help balance (Toulotte, Toursel, \& Olivier, 2012), fitness, and even cognitive abilities (Kooiman \& Sheehan, 2015), although they seem to be mostly limited to light-tomoderate physical activity (Peng et al., 2013). These games allow for the extension of our sense of touch, mainly, and enable activities that would usually demand training outdoor to be performed at home. The reason video game companies took to making it a point to cater to fitness-conscious consumers might have been driven by an interest in improving the negative image of video games regarding health or an interest in opening up to less targeted markets including the elderly (Millington, 2014), but they have shown that video games need not be only seen as promoting a sedentary 
lifestyle and leading exclusively to numb fingers from dedicated keyboard or button-punching craze.

\section{Accountability}

Video games are built around the potential of direct feedback. Players immediately get a reaction of the game based on their actions. They are accountable for their behavior and their doings. Within this virtual world players know what they are doing and learn what consequences that they will have due to a feedback system. Such feedback system is divided into two layers. The first layer is the interaction with the game, where players get feedback from the programmed game. Jumping off a cliff will lead to the death of a character, completing a quest is rewarded with a new level and so on. Within the world the player learns what he/she can do and furthermore is always accountable for his/her actions. The second layer is the interaction with other players. Many games depend on the cooperation of players and players seek out their role within those worlds (Taylor et al., 2015). In addition players are accountable for their reputation within the world. If players follow a certain set of rules of interaction (for example, to be nice, punctual or reliable), they are invited into groups or guilds, whereas being rude or bad-mouthed often leads to banishment. Such banishment can be enforced by the game developer or by the players. Players are always accountable for their actions and they notice this accountability.

Actions have consequences. That seems an aphorism everybody accepts. However, actions and consequences are more and more decoupled in today's society, whether due to time differences, geographical distance, quantity of participants, or just simply because of their complexity. Such effects weaken the general accountability, and examples like global warming or national debts reveal such decoupling between actions and consequences. Consequences are neglected or overseen. However, players are trained that any decision they make may lead to catastrophic effects. Furthermore, they see cause and effect still more clearly than non-players. Doing something good may not immediately change the world, but they are accountable for their portion of reality. At the very least they improve their own reputation and through it, they improve their direct surroundings. 


\section{Discussion}

Although it is still highly disputed whether video games are beneficial or harmful, it is nonetheless evident that they have a strong impact as media. Such claim is undeniable and the evidence is even stronger as video games become a more integral part of our media diet. US-American DFC Intelligence, a video gaming market research company, forecasts the revenue in the video game industry will rise to $\$ 100$ billion in 2018 (Brightman, 2014), whereas Newzoo is even more optimistic assessing the global gaming market will reach $\$ 113$ billion in revenue by 2018 (McDonald, Warman \& Stewart, 2015). Because of the difference between them and "old" media, and especially because of interactivity, video games have altered our perception of reality even further. As we play, we alter our definition of reality because we expand the possibilities of our senses, the abilities and skills we can perform through them. Such change could be as simple as an improvement in hand-eye-coordination, or the development of soft skills for international and intercultural team cooperation. Moral choices, with clear consequences in game-play, lead to better understanding of legal debates and may increase the sensitivity towards the other. Contrary to other media, which foster such change through manipulation or only after personal reflection - therefore with a time lag -, video games trigger such changes immediately, through interaction, and may be trained or developed over time. In the end, video games are a medium but they develop an environment and space that can be directed by the players. Players are the tinkers of video games and challenge their limits. Learning such behaviour will definitely swap over back and forth between the game and "reality" which in turn is a good thing. Because the reality we are often told to accept is broken, boring, unchallenging and feels beyond the reach of our actions. And our world will depend on people that are happy, sociable, constructors of meaning, morally conscious, changeable, adaptable, capable, tenacious and accountable.

To realize that video games are an environment is to recognize they are not an escape from reality, but rather its extension. From a macro-perspective they seem to embody the ultimate arch-myth supported on electronic media. They are a new space of debate, of cultural production and of physical impact. From the numb thumbs of kids playing in 
their consoles for hours, commuters suffering from neck injuries from playing social and leisure games on their mobiles and old people practising complex dance choreographies to rehabilitate from hip-replacement surgeries, to the pleasure of an Easter Egg hunt that leads to the discovery of the aesthetic influences, audio-visual repertoires and personal tastes of developers, video games have become a new frame of reference to judge our everyday lives. They are no longer a fad or the realm of the initiated. They are our reality.

\section{References}

Aarseth, E. J. (1997). Cybertext: Perspectives on ergodic literature. Baltimore and London: Johns Hopkins University Press.

Aguilera, J. (2014). Mindful embodiment in synthetic environments. Metaverse Creativity, 4(1), 5-14. doi:10.1386/mvcr.4.1.5

Anderson, S. L. (2013). Start, select, continue: The ludic anxiety in video game scholarship. Review of Communication, 13(4), 290-301. do i: $10.1080 / 15358593.2014 .886333$

Apperley, T. H. (2006). Genre and game studies: Toward a critical approach to video game genres. Simulation \& Gaming, 37(1), 6-23. doi: $10.1177 / 1046878105282278$

Armstrong, S. J., \& Hird, A. (2009). Cognitive style and entrepreneurial drive of new and mature business owner-managers. Journal of Business and Psychology, 24(4), 419-430.

Atkins, B. (2006). What are we really looking at? The future-orientation of video game play. Games and Culture, 1(2), 127-140. doi: $10.1177 / 1555412008325485$

Bateman, C. (2014). Implicit game aesthetics. Games and Culture, 10(4), 389-411. doi:10.1177/1555412014560607 
Bertolini, R. \& Nissim, S. (2002). Video games and children's imagination. Journal of Child Psychotherapy, 28(3), 305-325. doi:10.1080/0075417021000022667

Bogost, I. (2007). Persuasive games: The expressive power of videogames. Literary linguistic computing (Vol.23). Cambridge \& London: The MIT Press. Retrieved February 22, 2015 from http://search.ebscohost.com/ login.aspx? direct=true $\& \mathrm{db}=\mathrm{a} 9 \mathrm{~h} \& \mathrm{AN}=37562275 \&$ site $=$ ehost-live

Bourgonjon, J., Wever, B. De, Soetaert, R. \& Valcke, M. (2015). Players ' perspectives on the positive impact of video games : A qualitative content analysis of online forum discussions. New Media \& Society, 1-18. doi:10.1177/1461444815569723

Brightman, J. (2014). Game software market to hit $\$ 100$ billion by 2018 - DFC. Retrieved February 22, 2015 from http://www.gamesindustry.biz/articles/2014-06-25-game-software-market-to-hitusd100-billion-by-2018-dfc. Retrieved at 08/28/2015.

Brookey, R. A., \& Booth, P. (2006). Synergy and the Limits of Interactivity in The Lord of the Rings: The Return of the King Video Game. Games and Culture, 1(3), 214-230. doi:10.1177/1555412006290441

Chen, C.-Y. (2013). Is the video game a cultural vehicle? Games and Culture, 8(6), 408-427. doi:10.1177/1555412013493349

Csikszentmihalyi, M. (1991). Flow the psychology of optimal experience. New York: HarperPerennial.

Dendle, P. (2007) The zombie as a barometer of cultural anxiety. In N. Sco$\mathrm{tt}$ (Ed.), Monsters and the monstrous. Myths and metaphors of enduring evil (pp. 45-58). Amsterdam: Editions Rodopi.

Duncan, S. C. (2011). Minecraft, beyond construction and survival. Well Played: A Journal on Video Games, Value and Meaning, 1(1), 1-22. 
Egenfeldt-Nielsen, S., Smith, J. H. \& Tosca, S. P. (2008). Understanding video games. New York \& London: Routledge.

Emmerich, R. (Director). (1996). Independence Day [Film]. USA: $20^{\text {th }}$ Century Fox.

ESA. (2014). Essential facts. Essential Facts about Games and Violence. Retrieved February 22, 2015 from http://www.theesa.com/wp-content/uploads/2015/02/ESA_EF_GamesandViolence.pdf

Ferguson, C. J. (2015). Does movie or video game violence predict societal violence? It depends on what you look at and when. Journal of Communication, 65(1), 193-212. doi:10.1111/jcom.12142

Frasca, G. (2003). Simulation versus narrative - introduction to ludology. In M. J. P. Wolf \& B. Perron (Eds.), The video game theory reader (pp. 221-235). New York: Routledge.

Gee, J. P. (2005). Learning by design: Good video games as learning machines. E-Learning and Digital Media, 2(1), 5-16

Granic, I., Lobel, A. \& Engels, R. C. M. E. (2014). The benefits of playing video games. American Psychologists, 69(1), 66-78.

Grizzard M., Tamborini, R., Lewis, R.J., Wang L. \& Prabhu S. (2014). Being bad in a video game can make us morally sensitive.Cyberpsychology, Behavior, and Social Networking,17(8), 499-504. doi:10.1089/ cyber.2013.0658.

Huizinga, J. (1949). Homo ludens. A study of the play-element in culture. London: Routledge.

Jenkins, H. (2004). Game design as narrative architecture. In N. WardripFruin \& P. Harrigan (Eds.), First person: New media as story, performance and game (pp. 118-130). Cambridge, Massachusets, London: The MIT Press. 
Juul, J. (2013). The art of failure. An essay on the pain of playing video games. Cambridge, MA: MIT Press.

Khoo, A. (2012). Video games as moral educators? Asia Pacific Journal of Education, 32(4), 416-429. doi:10.1080/02188791.2012.738638

Kline, S., Dyer-Witheford \& De Peuter, G. (2003). Digital play. Montreal \& Kingston: McGill-Queen’s University Press.

Kloos, A. D., Fritz, N. E., Kostyk, S. K., Young, G. S. \& Kegelmeyer, D. A. (2013). Video game play (Dance Dance Revolution) as a potential exercise therapy in Huntington's disease: a controlled clinical trial. Clin Rehabil,27(11), 972-982. doi:10.1177/0269215513487235

Kooiman, B. J., \& Sheehan, D. P. (2015). Interacting with the past, present, and future of exergames: At the beginning of a new life cycle of video games? Loisir et Société / Society and Leisure, 38(1), 55-73. doi:10.1080/07053436.2015.1006960

Koster, R. (2014). A theory of fun for game design. A theory of fun for game design (2nd ed.). Sebastopol: O’Reilly Media, Inc.

Kücklich, J. (2005). Precarious playbour: Modders and the digital games industry. Fibreculture, 3.

Lellock, J. (2015). Media review: papers, please (2013) work simulation role-playing video game. Humanity \& Society, 39(1), 121-123. doi: $10.1177 / 0160597614566347$

Light, J. (2008). Taking games seriously. Technology and Culture, 49(2), 347-375. doi:10.1353/tech.0.0007

March, J. G. (1991). Exploration and exploitation in organizational learning. Organization Science, 2(1), 71-87. 
Martin, M. (2011, February 11). "Gamer regret” one of the biggest obstacles to industry growth. Retrieved february 22, 2015 from http:// www.gamesindustry.biz/articles/2011-02-11-gamer-regret-oneof-the-biggest-obstacles-to-industry-growth

McDonald, E., Warman, P. \& Stewart, D. (2015). The consumer as producer. How games \& video converge to drive growth. Newzoo Free Whitepaper (Vol. 1). Retrieved february 22, 2015 from www.newzoo.com

McGonigal, J. (2008). Engagement economy. Technology Horizons, (September), 1-21.

McGonigal, J. (2011). Reality is broken: Why games make us betterand how they can change the world. New York: The penguin press.

McLuhan, E. (2008). Marshall McLuhan's theory of communication: The yegg. Global Media Journal -- Canadian Edition, 1(1), 25-43.

McLuhan, M. (1967). The invisible environment: The future of an erosion. Perspecta, 11(1), 163-167.

McLuhan, M. (1996a). Comprender los medios de comunicación. Las extensiones del ser humano. Barcelona: Paidós.

McLuhan, M. (1996b). Playboy interview. A candid conversation with the high priest of pop cult and metaphysician of media. In E. McLuhan \& F. Zingrone (Eds.), Essential McLuhan (pp. 233-269). New York: Basic Books.

Medler, B. (2011). Player dossiers: Analyzing gameplay data as a reward. Game Studies, 11(1).

Millington, B. (2014). Video games and the political and cultural economies of health-entertainment. Leisure Studies, 1-19. doi:10.1080 /02614367.2014.986511 
Newbery-Jones, C. J. (2015). Law and humanities answering the call of duty: the phenomenology of justice in twenty-first-century video games. Law and Humanities, 9(1), 78-102. doi:10.1080/175214 83.2015.1042218

Ott, B., \& Walter, C. (2000). Intertextuality: Interpretive practice and textual strategy. Critical Studies in Media Communication, 17(4), 429446. doi: $10.1080 / 15295030009388412$

Pearce, C. (2007). Communities of play: The social construction of identity in persistent online game worlds. Second Person RolePlaying and Story in Games and Playable Media, 1, 1-7. doi:10.1111/14679213.00048

Peng, W., Crouse, J. C., \& Lin, J. H. (2013). Using active video games for physical activity promotion: a systematic review of the current state of research. Health Educ Behav, 40(2), 171-192. doi:10.1177/1090198112444956

Roncallo-Dow, S. (2011). Más allá del espejo retrovisor. La noción de medio en Marshall McLuhan. Bogotá: Editorial Pontificia Universidad Javeriana.

Roncallo-Dow, S., \& Uribe-Jongbloed, E. (2013). El medio es el mito: Entre McLuhan y Barthes. Universitas Philosophica, 30(61), 21-47.

Roncallo-Dow, S., Uribe-Jongbloed, E., Barker, K., \&Scholz, T. M. (2013). Authorship in virtual worlds: Author's death to rights revival?Journal For Virtual Worlds Research, 6(3), 1-15.

Rosser, J. C., Lynch, P. J., Cuddihy, L., Gentile, D. A., Klonsky, J. \& Merrell, R. (2007). The impact of video games on training surgeons in the 21st century. Archives of Surgery, 142(2), 181-186.

Rushkoff, D. (2011). Renaissance now! The gamers' perspective. In J. Raessens \& J. Goldstein (Eds.), Handbook of computer game studies (pp. 415-422). Cambridge \& London: The MIT Press. 
Rushkoff, D. (2013). Present shock: When everything happens now. New York: Penguin Group.

Schell, J. (2015). The art of game design: A book oflenses (2nd ed.). Boca Raton, London, New York: CRC Press.

Scholz, T. M. (2010). What can we learn from game leadership? Presented at the IX World Media Economics and Management Conference, Bogotá, Colombia.

Scholz, T. M., (2013). Does context matter? Conceptualizing relational contextualization. In K. Mitgutsch, S. Huber, J. Wimmer, M. G. Wagner, \& H. Rosenstingl, Herbert (Eds.), Context matters! Exploring and reframing games and play in context (pp. 89-98). Wien: New Academic Press.

Schrader, P. G., Lawless, K. A. \& Mccreery, M. (2009). Intertextuality in massively multiplayer online games. In R. E. Ferdig (Ed.), Handbook of research on effective electronic gaming in education (pp. 791807). IGI Global.

Schulzke, M. (2010). Defending the morality of violent video games. Ethics and Information Technology,12(2), 127-138. doi:10.1007/s10676010-9222-x

Scolari, C. A. (2012). Media ecology: Exploring the metaphor to expand the theory. Communication Theory, 22(2), 204-225. doi:10.1111/ j.1468-2885.2012.01404.x

Spigel, L. (2004). Entertainment wars: Television culture after 9/11. American Quarterly, 56(2), 235-270

Spring, D. (2014). Gaming history: Computer and video games as historical scholarship. Rethinking History, 19(2), 207-221. doi:10.1080 /13642529.2014.973714 
Strate, L. (2008). Studying media as media: McLuhan and the media ecology approach. Media Tropes, 1(1), 127-142.

Taylor, N., Bergstrom, K., Jenson, J., \&de Castell, S. (2015). "Alienated playbour: Relations of production in EVE online.Games and Culture, 10(4), 365-388.

Taylor, T. L. (2012). Raising the stakes: The professionalization of computer gaming. Cambridge, MA: MIT Press.

Thiagarajan, S. (2015). Playing Works! Retrieved february 22, 2015 from http://www.thiagi.com/games/2015/7/7/aug-playing-works

Totilo, S. (2013). Two thirds of you played Mass Effect 3 as a paragon. Mostly as Soldiers. Retrieved at 08/08/2015 from http://kotaku. com/5992092/two-thirds-of-you-played-mass-effect-3-as-a-paragon-mostly-as-soldiers.

Toulotte, C., Toursel, C. \& Olivier, N. (2012). Wii Fit(R) training vs. adapted physical activities: Which one is the most appropriate to improve the balance of independent senior subjects? A randomized controlled study. Clinical Rehabilitation, 26(9), 827-835. doi:10.1177/0269215511434996

Ulas, E. S. (2014). Virtual environment design and storytelling in video games. Metaverse Creativity, 4(1), 75-92. doi:10.1386/mvcr.4.1.75

Weaver, A. J., \& Lewis. N. (2012). Mirrored morality: An exploration of moral choice in video games. Cyberpsychology, Behavior, and Social Networking,15(11), 610-614. doi:10.1089/cyber.2012.0235.

Weinel, J., Griffiths, D., \& Cunningham, S. (2014). Easter eggs: Hidden tracks and messages in musical mediums. In Proceedings - 40th International Computer Music Conference, ICMC 2014 and 11 th Sound and Music Computing Conference, SMC 2014 - Music Technology 
Meets Philosophy: From Digital Echos to Virtual Ethos (pp. 140147). National and Kapodistrian University of Athens.

Williams, D., Yee, N., \& Caplan, S. E. (2008). Who plays, how much, and why? Debunking the stereotypical gamer profile. Journal of Computer-Mediated Communication, 13(4), 993-1018. doi:10.1111/ j.1083-6101.2008.00428.x

Wolf, M. J. P. (2001). The video game as a medium. In M. J. P. Wolf (Ed.), The medium of the video game (pp. 29-49). Austin: University of Texas Press.

Wolf, M. J. P. (2006). Game studies and beyond. Games and Culture, 1(1), 116-118. doi:10.1177/1555412005281787

\section{Ludography}

Bioshock (2007). Boston, MA, USA: Irrational Games.

Dance Dance Revolution (1998). Tokyo, Japan: Konami.

Fallout 3 (2008). Rockville, MD, USA: Bethesda Gameworks

Halo (2001). Chicago, IL, USA: Bungie.

Kingdom Rush (2011). Montevideo, Uruguay: Ironhide Game Studio.

Mass Effect (2007). Edmonton, Canada: Bioware.

Metal Gear Solid 3 (2004). Roppongi, Japan: Kojima Productions.

Papers, please (2013). Http://papersplea.se :3909 LLC.

World of Warcraft (2004). Irvine, CA, USA: Blizzard. 